\title{
Factors Affecting Voluntary Staff Turnover: A Case Study Of Springs Parklands Hospital, South Africa
}

\author{
Dr. Abhinanda Gautam \\ Senior Facilitator, Regenesys Business School, Johannesburg \\ Ikhona Tuswa
}

doi: 10.19044/esj.2016.v12n10p197 URL:http://dx.doi.org/10.19044/esj.2016.v12n10p197

\begin{abstract}
The aim of this study is to examine the relationship between perceived availability of opportunities for promotion, training, career progression, existing management style and voluntary staff turnover intention among the nurses working at Springs Parklands Hospital. A quantitative, descriptive correlational design is used. Full time staff nurses $(\mathrm{N}=200)$ were surveyed. The findings revealed that all the four variables were significantly and negatively correlated to the intention to quit and predicted $(16.8 \%)$ of the variance in intention to leave scores. Management style is the strongest predictor of intent to leave (14.5\%). Nurses perceiving their managers as participatory had lower intention to leave. To retain qualified personnel, hospital administrators should focus on participative management style and career development programs that address the needs of the staff and the hospital.
\end{abstract}

Keywords: Staff Turnover, health sector, training, career development, management style, promotional opportunities, and voluntary labour

\section{Introduction}

In 2006, the World Health Organization report, estimated that out of the 57 countries under study, the critical shortages of nurses, doctors and midwives had reached an alarming global deficit of 2.4 million. These shortfalls were greatly experienced in the sub-Saharan Africa region. In the same report, out of 59.2 million full-time paid health workers globally, only $67 \%(39,470,000)$ where recorded as health service providers and the remaining 33\% $(19,750,000)$ being accounted for as health management and support employees. These statistics show that there are only 9.3 health workers available to serve a 1,000 people globally. In Africa however, the 
scenario is completely different. The total health care workforce in Africa is estimated to amount to $1,640,000$, with the average being 2.3 health workers per every 1,000 people identified (World Health Report, 2006:63).

The key challenges that is faced by the health policy makers is recruiting and keeping the right staff in a system where Health Human Resources (HHR) is central and essential for delivering care to the patients. It is therefore suggested that recruitment and retention problems that are currently faced be appropriately addressed since staff shortages or unmotivated health workforce is most probably to lead to adverse effects on health services delivery (Zurn, Dolea \& Stilwell 2005:7). This study is focussed on the factors that are affecting the voluntary nursing staff turnover at Springs Parklands Hospital. It focuses on organisational factors that management has some considerable control. The four major variables include the professed availability of promotional prospects, training prospects, career development prospects and the management style used to manage nurses working at Springs Parklands Hospital are considered, and their relationships with voluntary nursing staff turnover objective tested.

In any health system, the human resource element is vital to the delivery of care to patients and hence the shortage of nurses is likely to have adverse effects on delivering good health care services and the outcome of care (Zurn et al 2005:7). The findings of this study can assist the health professionals by given them more information as to why a rise in voluntary nursing turnover exists and at the same time develop strategies that can aid in improving human resources management to reduce voluntary staff turnover in hospitals.

\section{Literature review}

Inevitably, in numerous countries reviewed in this section of the study, there exist a great deficiency of nurses hence a big public health challenge, resulting in government recalling health care professionals in formal employment and in the care organizations to augment the health workers gap from the market (Goodin 2003:335). Furthermore, nurse turnover is costly for hospitals and leads to scarcities at the unit level (Aiken, Buchan, Ball \& Rafferty 2008:3335).

In addition, increased nurse throughput can influence negatively on an organizations capability to fulfil patients' requirements as well as deliver quality care (Shields \& Ward 2001:698). By virtue, Cavanagh and Coffin (1992:1369) note that nursing staff turnover ensures an influence on staff morale and working exercise, which could have aun favorable effect on patient care. In trying to understand the factors that affect staff turnover, earlier authors tended to focus more on the psychological path that individuals take when quitting a job (Mobley 1977:237), behavioral 
experiences (Steel \& Ovalle 1984:673) and processes by which jobholders consider work potentials (Lee \& Mitchell 1994:51).

Academics such as Mayer and Schoorman (1998:15) put importance on organizational obligation in determining the level of turnover whereas others like Sager, Griffeth and Hom (1998:254) focused on cognitive process. Fischer, Hinson and Deets (1994:950) noted that while factors that impact on turnover are outside the control of health service managers, managers could prejudice many.

In addition, the dictum turnover can be valuable if it permits the company to hire new employees with more existing training. New ideas from outsiders can be serious to companies that are not progressing and are in great want of innovation. Also, turnover creates opportunities to enhance high performers and talented people. When poor performers or troublemaking employees leave the company, it occasionally leads to surge in confidence among co-workers (Mello 2006:569).

Numerous studies have examined influences that dispose nurse turnover. Thereafter, prototypes of nurse turnover have shown it as a function of job gratification, influenced by variables like demographic and environmental conditions, company factors, professional and personal issues (Hongoro \& Normand 2006:1311); Shields \& Ward 2001:677; Dussault \& Franceschini 2006:7), by means of intention to depart the most instantaneous determining factor of definite turnover (Tan 2008:9) citing Mobley, Horner and Hollingsworth (1978).

Amongst the explanations given for great staff turnover, lack of attention from managers, poor training, pay, promotion associated problems, development opportunities and underprivileged standards of administration similar uncaring and distant managers unapproachable, (Bratton \& Gold 2007:205) citing Bevan (1991).

In South Africa, abrasion among enrolled midwives and nurses in private and nonprofit making hospitals increased from 25\% in the year $2006 / 2007$ to $32 \%$ in $2007 / 2008$ before reducing to $30 \%$ in $2008 / 2009$ and dropped to $26 \%$ in $2009 / 2010$. Although retention has persisted a test to the remote on for profit amenities principally because of financial constrictions, the absolute quantities of staff is continuously preserved due to speed auxiliary with new graduates. By virtue, the major challenge caused by staff turnover is consequently the loss of increased capacity to grow and the extra costs of adding new employees and deficiency of experience within the ministry of health (Ministry of Health 2010:160). Achievement of understanding in the way these nurses recognize their jobs, as well as the prominence they give to the numerous influences that impact staff turnover, will support in increasing policies for dropping staff exodus from South African hospitals. 


\section{Research methodology}

The research methodology utilised in this study is quantitative. Quantitative research is the investigation of occurrences that lend themselves to precise measurement and quantification, often comprising a rigorous and controlled design (Polit \& Beck 2004:729). This model is set out to examine relationships between variables, and statistical tests were applied to decide whether the relationships identified above were significant or not.

\section{Research objectives}

The research objectives of this study are fourfold and are enumerated as follows;

- To ascertain the relationship between perceived availability of training opportunities and voluntary labour turnover among Springs Parklands Hospital staff;

- $\quad$ To determine the linkage between perceived availability of career development opportunities and voluntary labour turnover among Springs Parklands Hospital staff;

- $\quad$ To ascertain the relationship between perceived management style and voluntary labour turnover among Springs Parklands Hospital staff; and

- $\quad$ To determine the relationship between perceived availability of promotional opportunities and voluntary labour turnover intention among Springs Parklands staff.

\section{Study population}

In this study, the target population that is readily accessible is the entire staff constituent of nurses and midwives registered with the South African Nurses and Midwives Council employed by Springs Parklands Hospital on a full time basis. There were approximately 250 nurses employed by the hospital. 200 of them responded. In some instances, the sample may consist of all members of a specifically defined population particularly where the population of interest is not too large (Campbell, et al 2007:81). In this study, the population of interest is particularly small.

\section{Research findings}

The nurses were interviewed using the structures questionnaire and the following results were revealed. 


\section{Perceived organisational support and willingness to leave}

Table 4.1 The correlation between perceived organisational support and willingness to quit

\begin{tabular}{|c|c|c|c|}
\hline \multicolumn{2}{|c|}{} & Willingness to quit & $\begin{array}{c}\text { Perceived } \\
\text { organisational support }\end{array}$ \\
\hline \multirow{2}{*}{$\begin{array}{c}\text { Perceived } \\
\text { organisational support }\end{array}$} & $\begin{array}{c}\text { Pearson } \\
\text { correlation }\end{array}$ & -2.23 & 1 \\
\cline { 2 - 4 } & $\mathrm{N}$ & 200 & 200 \\
\cline { 2 - 4 } & $\begin{array}{c}\text { Pearson } \\
\text { correlation }\end{array}$ & 1 & -2.23 \\
\hline Willingness to quit & $\mathrm{N}$ & 200 & 200 \\
\hline
\end{tabular}

Correlation is significant at 0.05 level

The results revealed a strong negative correlation between perceived organisational support and the willingness of staff to quit. The Pearson's product-moment correlation (Pearson $r$ ) $=-2.23$ as reflected in table 4.1

\section{Perceived availability of training opportunities and willingness to} leave

The results revealed a strong negative correlation between perceived availability training opportunities and the willingness of staff to quit.

Table 4.2: The correlation between perceived availability of training opportunities and willingness to quit

\begin{tabular}{|c|c|c|c|}
\hline & & Willingness to quit & $\begin{array}{c}\text { Perceived availability } \\
\text { of training } \\
\text { opportunities } \\
\end{array}$ \\
\hline \multirow{3}{*}{$\begin{array}{c}\text { Perceived } \\
\text { availability of } \\
\text { training opportunities }\end{array}$} & $\begin{array}{c}\text { Pearson } \\
\text { correlation }\end{array}$ & -3.17 & 1 \\
\hline & $\mathrm{N}$ & 200 & 200 \\
\hline & $\begin{array}{c}\text { Pearson } \\
\text { correlation }\end{array}$ & 1 & -3.17 \\
\hline Willingness to quit & $\mathrm{N}$ & 200 & 200 \\
\hline
\end{tabular}

Correlation is significant at 0.05 level

The results revealed a strong negative correlation between perceived availiability of training opportunities and the willingness of staff to quit. The Pearson's product-moment correlation (Pearson r) $=-3.17$ as reflected in table 4.2

\section{Perceived availability of promotional opportunities and willingness to quit}

The results revealed a strong negative correlation between perceived promotional opportunities and the willingness of staff to quit. The Pearson's product-moment correlation (Pearson $\mathrm{r}$ ) $=-2.87$ as reflected in table 4.3 below. 
Table 4.3: The correlation between perceived availability of promotional opportunities and willingness to quit

\begin{tabular}{|c|c|c|c|}
\hline & & Willingness to quit & $\begin{array}{c}\text { Perceived availability } \\
\text { of promotional } \\
\text { opportunities }\end{array}$ \\
\hline \multirow{3}{*}{$\begin{array}{c}\text { Perceived } \\
\text { availability of } \\
\text { promotional } \\
\text { opportunities }\end{array}$} & $\begin{array}{c}\text { Pearson } \\
\text { correlation }\end{array}$ & -2.87 & 1 \\
\hline & $\mathrm{N}$ & 200 & 200 \\
\hline & $\begin{array}{c}\text { Pearson } \\
\text { correlation }\end{array}$ & 1 & -2.87 \\
\hline Willingness to quit & $\mathrm{N}$ & 200 & 200 \\
\hline
\end{tabular}

Correlation is significant at 0.05 level

\section{Perceived availability of career development opportunities and willingness to quit}

The results revealed a strong negative correlation between perceived availability of career development opportunities and the willingness of staff to quit. The Pearson's product-moment correlation (Pearson r) $=-3.23$ as reflected in table 4.4 below

Table 4.4: The correlation between perceived availability of career development opportunities and willingness to quit

\begin{tabular}{|c|c|c|c|}
\hline & & Willingness to quit & $\begin{array}{c}\text { Perceived availability } \\
\text { of career development } \\
\text { opportunities }\end{array}$ \\
\hline \multirow{3}{*}{$\begin{array}{c}\text { Perceived } \\
\text { availability of career } \\
\text { development } \\
\text { opportunities }\end{array}$} & $\begin{array}{c}\text { Pearson } \\
\text { correlation }\end{array}$ & -3.23 & 1 \\
\hline & $\mathrm{N}$ & 200 & 200 \\
\hline & $\begin{array}{c}\text { Pearson } \\
\text { correlation }\end{array}$ & 1 & -3.23 \\
\hline Willingness to quit & $\mathrm{N}$ & 200 & 200 \\
\hline
\end{tabular}

Correlation is significant at 0.05 level

\section{Management style and intent to leave}

The results revealed a strong negative correlation between perceived management style and the willingness of staff to quit. The Pearson's productmoment correlation (Pearson r) $=-3.76$ as reflected in table 4.5 below.

Table 4.5: The correlation between perceived management style and willingness to quit

\begin{tabular}{|c|c|c|c|}
\hline \multirow{2}{*}{$\begin{array}{c}\text { Perceived } \\
\text { Panagement style }\end{array}$} & $\begin{array}{c}\text { Pearson } \\
\text { correlation }\end{array}$ & -3.76 & $\begin{array}{c}\text { Perceived } \\
\text { management style }\end{array}$ \\
\cline { 2 - 4 } & $\mathrm{N}$ & 200 & 1 \\
\cline { 2 - 4 } & $\begin{array}{c}\text { Pearson } \\
\text { correlation }\end{array}$ & 1 & 200 \\
\hline Willingness to quit & $\mathrm{N}$ & 200 & -3.76 \\
\hline
\end{tabular}

Correlation is significant at 0.05 level 


\section{Multiple regression analysis of the variables}

This section presents the multiple regression outcomes between employee turnover factors which encompass management style, career development opportunities, availability, training opportunities and the dependent variable of willingness to quit by employees.

Table 4.6 below depict the results of the multiple regressions.

\section{Promotion, training, career development, management style and willingness to leave}

Table 4.6 demonstrates the results of the multivariate regression model. The dependent variable is a score for willingness to quit whilst the perceived organisational support score is the control variable. Based on the outcomes of the regression analysis, management style had the largest effect (Beta = -3.12), perceived availability of career development had a moderately large effect (Beta $=-2.31$ ), perceived promotional opportunities had a relatively small effect (Beta $=-.075$ ) and training opportunities had the least effect (Beta $=-.054$ ). Imperative to pinpoint is that all independent variables combined together had $12.3 \%$ prediction accuracy with regard to predicting nurses’ willingness to quit.

Table 4.6: Results of the Multiple Regression Analysis for Voluntary turnover factors with intent to leave $(\mathrm{N}=200)$

\begin{tabular}{|c|c|c|c|c|c|c|c|c|}
\hline \multirow[t]{2}{*}{ Variables } & \multicolumn{2}{|c|}{$\begin{array}{c}\text { Unstandardised } \\
\text { Coefficients }\end{array}$} & \multirow{2}{*}{$\begin{array}{c}\begin{array}{c}\text { Standardised } \\
\text { coefficients }\end{array} \\
\text { Beta }\end{array}$} & \multirow[b]{2}{*}{$\mathrm{T}$} & \multirow[b]{2}{*}{ Sig. } & \multirow[b]{2}{*}{$\begin{array}{c}\text { Total } \\
\text { R- } \\
\text { squared }\end{array}$} & \multirow[b]{2}{*}{ F } & \multirow[b]{2}{*}{ Significance } \\
\hline & B & $\begin{array}{l}\text { Std. } \\
\text { Error }\end{array}$ & & & & & & \\
\hline (Constant) & 5.213 & .587 & & 10.62 & .000 & & & \\
\hline $\begin{array}{c}\text { Perceived } \\
\text { availability of } \\
\text { training } \\
\text { opportunities }\end{array}$ & -.076 & 0.082 & -.054 & -.876 & .654 & & & \\
\hline $\begin{array}{c}\text { Perceived } \\
\text { availability of } \\
\text { promotional } \\
\text { opportunities }\end{array}$ & -.076 & .128 & -.075 & -.756 & .443 & .123 & 12.13 & .00 \\
\hline $\begin{array}{c}\text { Perceived } \\
\text { availability of } \\
\text { career } \\
\text { development and } \\
\text { promotional } \\
\text { opportunities }\end{array}$ & -.267 & .142 & -.231 & -.891 & .041 & & & \\
\hline $\begin{array}{l}\text { Management } \\
\text { style }\end{array}$ & -.621 & .152 & -.312 & -3.12 & .005 & & & \\
\hline
\end{tabular}

\section{Analysis of variance (anova)}

ANOVA analysis conducted solely to determine differences in group means for willingness to quit amongst the participants. The ANOVA 
performed is based on participants' disaggregation on age, number of years spent at work, levels of education and current position held. Tables 4.7.1, 4.7.2, 4.7.3 and 4.7.4 will provide the descriptive outputs of the ANOVA.

\section{Age of respondents and willingness to quit}

ANOVA test is conducted to allow for comparative analysis of the mean scores of the willingness to quit among varying age groups. According to table 4.8 below, the $\mathrm{F}$ statistic of 2.066 is insignificant at 0.053 , which exceeded the minimum 0.05 that is required for statistical significance. There the null hypothesis is accepted of no difference among the average scores of willingness to quit and the conclusion that nurses' willingness to quit could not be linked to the age differences that characterised the participants.

Table 4.7.1: $\quad$ Comparison of means for turnover intention among the different age

\begin{tabular}{|c|c|c|c|c|c|c|}
\hline $\begin{array}{c}\text { Age of groups } \\
\text { of respondents }\end{array}$ & $\mathrm{N}$ & Mean & $\begin{array}{c}\text { Std. } \\
\text { Deviation }\end{array}$ & $\begin{array}{c}\text { Std. } \\
\text { Error }\end{array}$ & $\mathrm{F}$ & Significance \\
\hline 20-20 years & 67 & 3.8 & .9723 & .425 & 2.066 & .0052 \\
\hline 31-40 years & 77 & 3.23 & 1.541 & .412 & & \\
\hline 41-50 years & 43 & 3.76 & 1.053 & .431 & & \\
\hline 51-60 years & 13 & 3.4 & 1.067 & .418 & & \\
\hline Total & 200 & & & & & \\
\hline
\end{tabular}

\section{Number of years respondents have worked in springs parklands hospital and willingness to quit}

ANOVA test conducted to allow for comparative analysis of the mean scores of the willingness to quit among varying number of years they have worked at Springs Parklands Hospital. According to table 4.9 below, the $\mathrm{F}$ statistic of 0.552 is insignificant at 0.064 , which is exceeded the minimum 0.05 that is required for statistical significance. There the null hypothesis is accepted of no difference among the average scores of willingness to quit and the conclusion that nurses' willingness to quit could not be linked to the number of years participants have worked at Springs Parkland Hospital.

Table 4.7.2 Comparison of means for turnover intention among respondents disaggregated by the number of years worked in Springs Parklands Hospital

\begin{tabular}{|c|c|c|c|c|c|c|}
\hline $\begin{array}{c}\text { Groups of } \\
\text { respondents } \\
\text { according to years } \\
\text { worked at Springs } \\
\begin{array}{c}\text { Parklands } \\
\text { Hospital }\end{array}\end{array}$ & $\mathrm{N}$ & Mean & $\begin{array}{c}\text { Std. } \\
\text { Deviation }\end{array}$ & $\begin{array}{c}\text { Std. } \\
\text { Error }\end{array}$ & $\mathrm{F}$ & Significance \\
\hline Less than 3 years & 30 & 3.188 & .9453 & .410 & 0.522 & .064 \\
\hline 3-5 years & 22 & 3.123 & 1.341 & .467 & & \\
\hline Above 5 years & 148 & 3.142 & 1.145 & .471 & & \\
\hline Total & 200 & & & & & \\
\hline
\end{tabular}




\section{Education level of respondents and willingness to quit}

ANOVA test is conducted to allow for comparative analysis of the mean scores of the willingness to quit among varying education levels. According to table 4.10 below, the F statistic of 1.87 is insignificant at 0.123 , which is exceeded the minimum 0.05 that is required for statistical significance. There the null hypothesis is accepted of no difference among the average scores of willingness to quit and the conclusion that nurses' willingness to quit could not be linked to the participants' level of education.

Table 4.7.3 Comparison of means for turnover intention among the respondents disaggregated by highest level of education

\begin{tabular}{|c|c|c|c|c|c|c|}
\hline $\begin{array}{c}\text { Groups of } \\
\text { respondents } \\
\text { according to level of } \\
\text { education }\end{array}$ & $\mathrm{N}$ & Mean & $\begin{array}{c}\text { Std. } \\
\text { Deviation }\end{array}$ & Std. Error & $\mathrm{F}$ & Significance \\
\hline Enrolled nurse & 68 & 3.54 & .959 & .497 & 1.87 & .123 \\
\hline Registered nurses & 64 & 3.87 & 1.412 & .463 & & \\
\hline Registered midwives & 52 & 3.23 & 1.091 & .412 & & \\
\hline Graduate nurses & 16 & 3.09 & 1.198 & .476 & & \\
\hline Total & 200 & & & & & \\
\hline
\end{tabular}

\section{Current position of respondents and willingness to quit}

ANOVA test is conducted to allow for comparative analysis of the mean scores of the willingness to quit among varying positions held. According to table 4.11 below, the $\mathrm{F}$ statistic of 1.712 is insignificant at 0.124 , which exceeded the minimum 0.05 that is required for statistical significance. There the null hypothesis is accepted of no difference among the average scores of willingness to quit and the conclusion that nurses' willingness to quit could not be linked to the different positions held by the participants.

Table 4.7.4: Comparison of means for turnover intention among respondents disaggregated by the current position held in Springs Parklands Hospital

\begin{tabular}{|c|c|c|c|c|c|c|}
\hline $\begin{array}{c}\text { Groups of } \\
\text { respondents } \\
\text { according to } \\
\text { current position } \\
\text { held }\end{array}$ & $\mathrm{N}$ & Mean & $\begin{array}{c}\text { Std. } \\
\text { Deviation }\end{array}$ & Std. Error & $\mathrm{F}$ & Significance \\
\hline Nurse & 120 & 3.182 & 1.213 & .234 & 1.712 & .124 \\
\hline Administration & 8 & 3.102 & 1.342 & .321 & & \\
\hline Unit in charge & 28 & 3.421 & 1.006 & .231 & & \\
\hline Supervisor & 44 & 3.343 & 1.062 & .343 & & \\
\hline Total & 200 & & & & & \\
\hline
\end{tabular}

\section{T-test analysis}

This section deals with the t-test results executed primarily to test the differences of group mean scores for willingness to quit in relation to gender 
and membership in a health worker's union. Table 4.11.1 and 4.11.2 respectively presents results of the t-tests for gender and membership to a health worker's union.

\section{Membership in health workers' union and willingness}

to quit

The t-test is conducted to allow for comparative analysis of the mean scores of the willingness to quit among members of a health workers' union and those that are not. According to table 4.12 below, the F statistic of 1.087 is insignificant at 0.276 , which exceeded the minimum 0.05 that is required for statistical significance. Thus the null hypothesis is accepted because of no difference among the average scores of willingness to quit and the conclusion that nurses' willingness to quit could not be linked to membership in a health workers' union.

Table 4.8.1: Comparison of means for turnover intention among respondents who are membership in a health workers' union with those who are not members

\begin{tabular}{|c|c|c|c|c|}
\hline $\begin{array}{c}\text { Groups of respondents } \\
\text { according to membership } \\
\text { in a health workers' union }\end{array}$ & $\mathrm{N}$ & Mean & t-test & Std. Error \\
\hline $\begin{array}{c}\text { Not members of a health } \\
\text { workers' union }\end{array}$ & 64 & 3.531 & 1.087 & .276 \\
\hline $\begin{array}{c}\text { Members of health } \\
\text { workers' union }\end{array}$ & 136 & 3.068 & & \\
\hline
\end{tabular}

\section{Gender of respondents and willingness to quit}

The t-test is conducted to allow for comparative analysis of the mean scores of the willingness to quit among males and females. According to table 4.13 below, the $\mathrm{F}$ statistic of 1.087 is insignificant at 0.276 , which exceeded the minimum 0.05 that is required for statistical significance. There the null hypothesis is accepted of no difference among the average scores of willingness to quit and the conclusion that nurses' willingness to quit could not be linked to the gender of participants.

Table 4.8.2 Comparison of means for turnover willingness among participants based

on gender

\begin{tabular}{|c|c|c|c|c|}
\hline Gender of participants & $\mathrm{N}$ & Mean & t-test & Std. Error \\
\hline Male & 64 & 3.672 & .837 & .532 \\
\hline Female & 136 & 3.154 & & \\
\hline
\end{tabular}

\section{Discussion of the findings of the study}

This chapter presented the analysis of results including biographical data. The analysis is carried out using frequency, Pearson correlation, descriptive statistics, multiple regression, ANOVA analysis and t-test analysis. The results revealed that there were significant negative correlation between the independent variables of perceived availability of promotional opportunities, training opportunities, career development opportunities, and 
management style, and the dependent variable of intent to leave. The results also showed that there is no influence of respondents' age, gender, number of years spent working in Springs Parklands Hospital, education level, current position held, and membership of health workers union on their intent to leave.

The foregoing findings advocated that while perceived availability of training opportunities is negatively connected with willingness to quit, the impact is negligible, which does not agree with some past studies, which discovered that perceived organisational support through training curtails turnover intentions (Collins et al 2000).

These findings corroborates with other studies, which have revealed that perceived organisational support had significant impact on staff turnover facilitated through normative commitment (Maertz et al 2007). Overall perceptions of employees, on the organisation's human resource practices forecast organisational commitment (Chang 2005).

This finding is reinforced by past studies, which declared that deficiency of career prospects is significantly related to reduced job fulfillment and consequently willingness to quit and that career development activities, followed by individuals, employers and professional organisations, would permit nurses to attain their best and lessen the willingness to quit (Collins et al 2000).

The findings above proposed that a perception of participative management style is linked with a declined willingness to quit, which agrees with past studies, which discovered that nurses falling under participative management style were unlikely to expect quitting their jobs and henceforth, lower turnover (Kim 2002:231).

\section{Scope OF FURTHER RESEARCH}

In a bid to improve the quality of these results, a longitudinal research inspecting the factors inducing to voluntary staff turnover amongst nurses and real turnover should be done to enlighten the process of improving the nursing conditions in both public and private hospitals.

In the same token, another study can be carried out focusing on application of diverse data analysis techniques such as non-parametric tests as well as studies of a qualitative nurture. There is a need in other words to verify analytical techniques that can help in securing reliable outcomes and there after accurate recommendations.

\section{Conclusion}

The study addressed the four research questions outlined in chapter one of the study. Overall, the four independent variables were significantly and negatively correlated with the dependent variable of willingness to quit. 
The independent variables had 12.3\% explanatory power of the nurses' willingness to quit their current employment at Parklands Springs Hospital. Once all four independent variables were exposed to multiple regression analysis, the findings discovered that perceived management style is the single most important voluntary nursing staff turnover variable accounting for most of the variance in the dependent variable of willingness to quit (Beta value $=-0.312$ ). The majority of respondents with the willingness to quit were unsatisfied with the management style. Springs Parklands Hospital has to instill and promote a culture of a participative style of management.

Additionally, the outcomes also portrayed that there is no influence of participants' gender, age, years spent working at Springs Parklands Hospital, education level, and membership in health workers', union current position held on their willingness to quit the Hospital. Imperative to highlight is that, the applicability of the study's findings is solely limited to nurses working at Springs Parklands Hospital and as such cannot be easily generalized to nurses working in other hospitals.

\section{References:}

Aiken, LH, Smith, HL \& Lake, ET. 1994. Lower Medicare mortality among a set of hospitals known for good nursing care. Medical Care 32(8):771-787. Bratton, J \& Gold, J. 2007. Human resource management: theory and practice. 4th edition. New York: Palgrave Macmillan.World Health Organization. 2006. World health report 2006. Working together for health. Geneva: World Health Organisation. (Online). http://www.who.int/whr/2006/en/ (accessed 30th July 2007).

Campbell, MJ, Machin, D \& Walters, SJ. 2007. Medical statistics: $a$ textbook for the health sciences. 4th edition. West Sussex, England: John Wiley \& Sons Ltd. Casio, WF. 2006: Managing human resources: productivity, quality of work life, profits. 7th edition. New York: McGrawHill. 94.

Cavanagh, SJ \& Coffin, DA. 1992. Staff turnover among hospital nurses. Journal of Advanced Nursing 17(11):1369-1376.

Chang, P-L, Chou, Y-C \& Cheng, F-C. 2007. Career needs, career development programmes, organizational commitment and turnover intention of nurses in Taiwan. Journal of Nursing Management 15(8):801810.

Collins, K, Jones, ML, McDonnell, A, Read, S, Jones, R \& Cameron, A. 2000. Do new roles contribute to job satisfaction and retention of staff in nursing and professions allied to medicine? Journal of Nursing Management 8(1):3-12.Zurn, P, Dolea, C \& Stilwell, B. 2005.

Dussault, G \& Franceschini, MC. 2006. Not enough there, too many here: understanding geographical imbalances in the distribution of the health 
workforce. Human resource for health 4:12. (Online). http://www.humanresources-health.com/content/4/1/12. (Accessed 30th July 2007).

Fischer, ML, Hinson, N \& Deets, C. 1994. Selected predictors of registered nurses $^{\text {ee }}$ intent to stay. Journal of Advanced Nursing 20(5):950-957.

Goodin, H. 2003. The nursing shortage in the United States of America: an integrated review of the literature. Journal of Advanced Nursing 43(4):335350 .

Hongoro, C \& Normand, C. 2006. Health workers: building and motivating the workforce. In: Jamison DT et al., eds. Disease control priorities in developing countries. 2nd edition. Washington, DC: The World Bank Group:1309-1322.

Kim, S. 2002. Participative management and job satisfaction: Lessons for management leadership. Public Administration Review 62(2):231-241. (Online). http://www.jstor.org/stable/3109906. (Accessed 7th October 2009). Maertz, CP, Griffeth, RW, Campbell, NS \& Allen, DG. 2007. The effects of perceived organisational support and perceived supervisor support on employee turnover. Journal of Organisational Behavior 28(8):1059-1075.

Mayer, RC \& Schoorman, FD. 1998. Differentiating antecedents of organisational commitment: a test of March and Simon ${ }^{e e}$ s Model. Journal of Organisational Behaviour 19(1):15-28. (Online). http://www.jstor.org/stable/3100225. (Accessed 7th October 2009).

Mello, JA. 2006. Strategic human resource management. 2nd edition. Ohio: South Western, Thomson. Mengo Hospital. 2008. Mengo hospital five year strategic plan 2008/9 - 2012/13. Kampala: Mengo hospital.

Ministry of Health. 2010. Annual health sector performance report. Kampala, Ministry of Health.

Mobley, HW. 1977. Intermediate linkages in the relationship between job satisfaction and employee turnover. Journal of Applied Psychology 62(2):237-240.

Nurse retention and recruitment: developing a motivated workforce. Geneva, World Health $\quad$ Organization. $106 \quad$ (Online). http://www.icn.ch/global/Issue4Retention.pdf (accessed 25TH July 2007).

Polit, DF \& Beck, CT. 2004. Nursing research: principles and methods. 7th edition. Philadelphia: Lippincott, Williams \& Wilkins.

Sager, JK, Griffeth, RW \& Hom, PW. 1998: A comparison of structural models representing turnover cognitions. Journal of Vocational Behavior, 53(2):254-273.

Shields, MA \& Ward, M. 2001. Improving nurse retention in the National Health Service in England: The impact of job satisfaction on intentions to quit. Journal of Health Economics 20(5):677-70. 
Steel, RP \& Ovalle, NK. 1984. A review and meta-analysis of research on the relationship between behavioral intentions and employee turnover. Journal of Applied Psychology 69(4):673-686.

Tan, F-M. 2008. Linking career development practices to turnover intention: the mediator of perceived organisational support. Journal of Business and Public Affairs 2(1):1-20. 